Izolda Khasaia,

Associate Professor

ORCID: 0000-0003-4199-9941

Akaki Tsereteli State University

Kutaisi, Georgia

\title{
POST-CRISIS TOURISM IN GEORGIA: STATE POLICY AND CORONAVIRUS FREE ZONES
}

Tourism is an important industry for the Georgian economy and also has an important social burden. The share of tourism in the country's economy is $11.5 \%$, the number of people employed in tourism is about $9 \%$ of the total number of employees.

Tourism received the most severe blow from the pandemic(COVID-19) and the first steps that the Georgian government took in support of business during the crisis period concerned tourism. The struggle with the pandemic is not over yet, but Georgia already has experience in a pandemic, how to manage a business in a crisis.About 19,000 citizens who during the pandemic arrived in Georgia in an organized manner from around the world with state support passed a 14-day quarantine period. For this, 83 hotels were involved.They gained extensive experience in crisis situations, serving people at high risk.

Georgia has safe coronavirus-free areas that are historically known as resorts for the rehabilitation of people with lung and respiratory problems:Tskhaltubo, Borjomi, Gudauri, Abastumani, Sairme, Bakhmaro.

Keywords: Tourism, Georgia, coronavirus, resorts, rural tourism.

Relevance of the research topic. «The worldwide outbreak of COVID-19 has brought the world to a standstill, and tourism has been the worst affected of all major economic sectors» [1]. But the time has come when states are already taking measures to gradually overcome the crisis, including in Georgia. The relevance of the topic is due to the need to analyze the current situation in Georgia's tourism in the context of a pandemic and government measures in support of business, and the possibility of developing «new demanded» tourism products in zones free of coronavirus.

Analysis of recent research and publications. Tourism should not inadvertently become the cause of the spread of the virus, so the European Union has already developed safe travel guidelines, which are planned to resume tourism in Europe this year [2]. The International Air Transport Association (IATA) has already published guidelines [3], Georgian government has developed anti-crisis tourism resumption plan [4]. 
Georgia has safe coronavirus-free areas that are historically known as resorts for the rehabilitation of people with lung and respiratory problems. In addition, rural, wine and other types of tourism are in demand in these areas (about it in more detail in articles [5-8]).

Presenting main material. The pandemic and restrictions imposed by the countries have made tourism one of the most affected sectors. At the same time, it occupies a crucial role in the global economy, providing a contribution of more than $10.3 \%$ of world GDP, generating more than $28 \%$ of world services exports and creating every tenth workplace in the world (330 million people). Tourism has a multiplier effect on employment in many related industries, including hotels and hotels, transportation, agriculture, finance, and construction.

Tourism is an important industry for the Georgian economy, as the share of tourism in the country's economy is $11.5 \%$, and the number of people employed in tourism is about $9 \%$ of the total number of employees [9].

Tourism is one of the fastest developing industries in Georgia (see Table). According to the Georgian National Tourism Administration, the number of International Traveler Trips increased by almost 72\% from 2015 to 2019. In 2019, the number of international visitors was 9.4 million, and revenue was \$ 3.3 billion. In January-February 2020, the number of international visitors increased by $10 \%$, and income by $6 \%$ compared to the same period in 2019 [10].

Table 1

\section{Dynamics of tourism development 2015-2019}

\begin{tabular}{|c|c|c|c|c|c|}
\hline Trip Types & 2015 & 2016 & 2017 & 2018 & 2019 \\
\hline $\begin{array}{c}\text { International } \\
\text { Traveler Trips }\end{array}$ & $6,305,635$ & $6,719,975$ & $7,902,509$ & $8,679,544$ & $9,357,964$ \\
\hline $\begin{array}{c}\text { International Visitor } \\
\text { Trips }\end{array}$ & $5,255,999$ & $5,392,816$ & $6,482,830$ & $7,203,350$ & $7,725,774$ \\
\hline $\begin{array}{c}\text { Tourist (Overnight) } \\
\text { Trips }\end{array}$ & $3,011,663$ & $3,297,275$ & $4,069,354$ & $4,756,820$ & $5,080,478$ \\
\hline Same Day Trips & $2,244,336$ & $2,095,541$ & $2,413,476$ & $2,446,530$ & $2,645,296$ \\
\hline Other (non-tourism) & $1,049,636$ & $1,327,159$ & $1,419,679$ & $1,476,194$ & $1,632,190$ \\
\hline
\end{tabular}

Source: Information Centre, Information and Analytical Department, Ministry of Internal Affairs of Georgia

Tourism received the most severe blow from the pandemic, and the first steps that were taken by the Georgian government in support of business during the crisis period concerned tourism. 
About 95\% of all tourism enterprises in Georgia are small and medium enterprises of business that do not have sufficient financial reserves to deal with the crisis independently and maintain jobs. But with the right support, tourism can become one of the important catalysts for the restoration of the country's entire economy. Therefore, in order to minimize the negative consequences of coronavirus, the Georgian government has proposed an anti-crisis plan in support of small and medium-sized businesses [4].

According to this plan, all business entities related to tourism receive a deferment until the end of 2020 on property tax and income tax (already deferred to 6118 businesses), for small hotels with a turnover of less than 6.3 million US dollars (20 million GEL), the state subsidizes bank interest loans at $80 \%$ for 6 months - this is more than $95 \%$ of existing hotels. Persons employed in the tourism industry who lost their jobs or were sent on free leave during the epidemic will receive \$ 380 (1200 GEL) for 6 months (\$ 62.4 per month), and self-employed will receive one-time help of about $\$ 100$. In addition, for each saved workplace with a salary of up to $\$ 500$ (1,500 GEL), the employer is exempt from income tax for 6 months.

For all tour companies connected to GDS, the state subsidizes the percentage of bank guarantees for 6 months. In support of guides, the state offers retraining programs for guides, free visits to museums, reserves, etc.

Unfortunately, the plan proposed by the Georgian government does not say anything separately about transport companies serving tourists and the financial support of guides.

Georgia will be one of the first countries to open its borders for tourism, taking into account the recommendations and standards of international organizations and the Ministry of Health - from June 15 for domestic tourism and July 1 for international visitors. Georgia already has certain competitive advantages for this. Georgia recognized internationally as a successful country in the fight against a pandemic. The decision made by the government to establish quarantine zones in hotels made it possible for 83 hotels to retain staff of up to 2500 people. After the borders were closed, more than 19,000 citizens were delivered to Georgia by special flights and all of them passed 14-day quarantine in these specially prepared hotels with all services (transportation, meals, etc.). Hotels received extensive experience in a work in a pandemic situation and manage a business in a crisis.

Georgia has the ability to set aside zones free from COVID-19. These are primarily resorts: Tskhaltubo, Borjomi, Gudauri, Abastumani, Sairme, Bakhmaro, which are historically known as resorts for the rehabilitation of people with problems with the lungs and respiratory organs. 
In addition, there are regions in Georgia, where not a single case of coronavirus has been recorded and there is an opportunity to develop popular tourism products. Such regions in Western Georgia include the following: Racha-Lechkhumi, Upper Svaneti and Guria. Each of these regions is interesting in its own way and is rich in both historical and cultural, as well as natural monuments, traditional typical cuisine for the region.

Consider the possibilities of one small region, less known than others, but quite interesting and unique in its untouched nature - this is the Guria region.

There are many attractions: two large monasteries - Shemokmedi and Jumati, the fortress of Queen Tamar, the fortress of Askan, about 20 Gurian temples and one mosque, but they are in poor condition. It is necessary to develop the infrastructure of these attractions, especially since they are located in very picturesque areas.

In Guria there is a part of Kolkheti National Park. This is a rather remarkable place, there are swamps and subtropical forests formed 65 million years ago. Naturally, these places are popular for hiking and bird watching. The region has a 20kilometer strip of seashore with a flat sandy beach suitable for swimming. Most of its territory is mountainous terrain, where nature is almost untouched. Guria is of great interest for ethnic and rural tourism, for lovers of traditions and ancient customs. Gurians sacredly honor ancient traditions and crafts. In most mountain villages, everything, like five hundred years ago, is done manually.

The traditions of choral singing have been preserved here, so tourists can enjoy national songs / polyphony and dances. Local artisans have preserved the ancient methods of honey separation, the manufacture of household items from clay and wood. Therefore, rural tourism products such as acquaintance with the culture of beekeeping, the production of beverages and products from honey, and the making of household items from clay or wood are popular here. They readily share their skills with travelers and invite them to take part in the «production» process.

In Guria in the village of Bakhmaro at an altitude of 2050 meters above sea level there is a famous national resort Bakhmaro, where the sea and mountain air merge, creating a unique environment. Therefore, it has natural healing properties.

It has fresh air, intense sun radiation, especially ultraviolet rays, low atmospheric pressure and a much higher oxygen content. The mountain climate has a tonic and invigorating effect on the human body. This is especially true for those who suffer from chronic compensated diseases of the lungs and heart.

After long months of isolation, when all restrictions on movement are lifted, people will have a desire to leave the city and relax in nature. It is important to offer 
such tourism products that cover the countryside, resorts, protected areas, nature reserves, i.e. virus free zones / safe zones.

Recently, there has been increased interest in rural tourism in Georgia. Many objects appeared especially near nature reserves, protected territories, famous historical and cultural monuments [5-8]. One example of a successful tourism business in a village is a home-type hotel - Agri guesthouse «Korena» in the village Gelati, about $10 \mathrm{~km}$ from Kutaisi. It is located next to the monument of world culture - the Gelati monastery complex (in the list of world cultural heritage sites of UNESCO since 1994).

An ecologically clean house typical of this region of Georgia is «Imereti Ode», which is 200 years old, typical household utensils, the possibility of walking through the picturesque nature, all this makes this place attractive for rest and rehabilitation after long months of quarantine. Fans of gastronomy tourism can get acquainted with the rich Imereti cuisine here, taste the varieties of wines typical of the region (here you can also find your own production and bottling). Thanks to the various services provided, this small facility employs 14 people. They have open spaces and the ability to receive tourists, both local and foreign, in compliance with all recommendations for safety. They are ready to host families, individual visitors, or a group of no more than 10 people (before the pandemic, they also hosted large groups, but, taking into account modern security requirements, they limited the number of guests).

Conclusions. Georgia already has experience and business management in crisis situations. She can create safe tourist areas. These are primarily resorts, which are historically known as resorts for the treatment and rehabilitation of people with health problems and especially with lungs, also protected areas, nature reserves, villages with a relatively developed infrastructure.

Recently, in Georgia, such tourism destinations have become in demand that become especially relevant in the post-crisis period, as cover coronavirus free zones. This is medical and health tourism, adventure tourism, rural tourism, eco, wine tourism, etc.

However, it is necessary to launch a campaign for the development of domestic tourism. For its quick restoration, the government must offer new opportunities, for example, partial budget financing, and discounts from business will also be effective. 


\section{REFERENCES}

1. https://www.unwto.org/tourism-covid-19

2. Tourism and transport: Commission's guidance on how to safely resume travel and reboot Europe's tourism in 2020 and beyond. May 13, 2020 by European Unionhttps://europeansting.com

3. Standards, Manuals \& Guidelines. https://www.iata.org/

4. Georgian Government Anti-Crisis Plan for Tourism Activation / Resumption. 2020-05-07 http://gov.ge/index.php?lang_id=GEO\&sec_ id=541\&info_id=76051

5. I. Khasaia. The Role Of Women In Small Scale Tourism Businesses In Rural Imereti (Georgia) In The Context Of Globalization. World Science. Warsaw: RS Global Sp. z O.O, 38(10), 2018

6. I. Khasaia, T. Arnania-Kepuladze, G. Kepuladze. The Role of Tourism In the Overcoming the Poverty In The Villages of Imereti Region. Proceedings of Materials of International Scientific-Practical Conference Actual Problems of Sustainable Development of National Economies, 7(1), 2015, 361-366

7. I. Khasaia. Perspectives of the Village Tourism Development in Imereti. E-Journal of the 1st International Conference Economic, Legal and Social Problems of Modern Development 1(1), 2015 http://atsu.edu.ge/EJournal/BLSS2015/

8. I. Khasaia, T. Abesadze. Research of the Need for Rural Tourism Products Among Students of Imereti Region (Georgia). VIth International Scientific-Practical Conference Proceedings, 6(1), 2017, 277-282

9. https://www.geostat.ge

10. Georgian National Tourism Administration -https://gnta.ge/statistics/

11. https://v-georgia.com/guriya-spokojnyj-otdyx-v-tixom-ugolke-na-zapadegruzii/ 